\title{
Rasionalitas dalam Ekonomi Islam
}

\author{
Muhammad Ngasifudin ${ }^{1}$ \\ STKIP Majenang \\ Jl. Raya Pahonjean KM 02. Po Box 25 (0280) 623622 Majenang-Cilacap-Jawa Tengah. \\ email:ngasifudinelaziz@gmail.com
}

\begin{abstract}
Islamic world view of the economy is based on a paradigm that justifies the social economy as its objectivity foundaton, by positioning the race on pole position than individual interests (self interest). according to the view of conventional economic, this case is extremely irriational and does not meet the requirements of transitivity. while the islamic economic rationality can be known on the principles of islamic economics and the basic principles of the system which can be owned.
\end{abstract}

Keyword : Rasionaliti, Islamic Economic, selfinterest to social interes

\begin{abstract}
ABSTRAK
Pandangan dunia Islam tentang ekonomi didasarkan pada suatu paradigma yang membenarkan ekonomi sosial sebagai dasar obyektifitasnya, dengan memposisikan umat dalam posisi terdepan dibanding kepentingan individu (self interest.) menurut pandangan ekonomi konvensional hal ini sangat tidak rasional dan tidak memenuhi persyaratan transitifitas. sedangkan rasionalitas ekonomi syariah dapat dilihat pada asas-asas ekonomi Syariah dan prinsip dasar sistem yang dipakai dimilikinya.
\end{abstract}

Kata Kunci : Rasionalitas, Ekonomi Islam, Kepentingan umat

\section{PENDAHULUAN}

Ilmu ekonomi merupakan suatu studi yang mempelajari tentang perilaku manusia. Dalam kapitalisme, studi yang dimaksud disini bukanlah manusia secara umum. Tetapi tentang manusia ekonomi yang memiliki perilaku untuk memenuhi segala kebutuhan hidupnya, baik kebutuhan primer maupun kebutuhan sekunder. untuk memenuhi kebutuhan tersebut maka manusia harus melakukan pilihan. Cara melakukan pilihan tersebut hanya dapat dilakukan oleh manusia ekonomi secara rasionalitas ekonomi.

Islam merupakan ajaran yang mengatur kehidupan dalam semua dimensi baik akidah, ibadah, dan semua aspek kehidupan manusia termasuk semua bentuk muamalah, khususnya pada hal-hal yang berkaitan dengan ekonomi. Tidak ada sesuatupun yang tersembunyi dari jangkauan Allah SWT dan tidak sesuatupun yang luput dari pengawasan-Nya.
Pemahaman tentang rasionalitas ekonomi sesungguhnya tidak bisa dipisahkan dari sistem ekonomi yang mendasarinya. Sistem dapat didefinisikan sebagi suatu organisasi yang terdiri dari berbagai unsur yang saling berhubungan satu sama lain, saling mempengaruhi dan bekerja sama untuk mencapai tujuan tertentu. Selanjutnya, dapat diatakan bahwa sistem ekonomi adalah organisasi yang terdiri dari bagian-bagian yang saling terkait dan bekerja sama untuk mencapai tujuan ekonomi (Nasution, 2007).

\section{METODE PENELITIAN}

Jenis penelitian yang digunakan dalam penulisan ini adalah library research karena kajiannya difokuskan pada bahan-bahan kepustakaan dengan menelusuri dan menelaah literatur-literatur yang berstandar akademik.

Dalam pembahasan ini menggunakan seperangkat proposisi yang terintegrasi secara

1 Phone 085601088847 
sintaksis, yaitu mengikuti aturan-aturan tertentu yang dapat dihubungkan secara logis satu dengan lainnya dengan data dasar yang dapat diamati. (Lexy J. Moleong, 2000).

\section{HASIL DAN PEMBAHASAN}

\section{Definisi Rasionalitas}

Rasionalitas menjadi membingungkan ketika dapat berarti banyak, seperti tidak memihak, beralasan, logis, dan mempunya maksud tertentu. Serta lebih lanjut keputusan rasional yang dibuat terkadang tidak selalu sesuai dengan yang diharapkan. Perbedaan pengertian rasional ini pun juga terjadi antara sesame ilmuwan sosial.(Rianto \& Amalia, 2010) Dimana rasionalitas menjadi topik yang kontroversial dan tidak ada defeni yang jelas, lugas, serta gamblang yang bisa diterima secara umum oleh semua pihak.

Dalam literature teori ekonomi modern, seorang pelaku ekonomi diasumsikan rasional berdasarkan kriteria berikut (Rianto \& Amalia, 2010), Setiap orang selalu tahu apa yang mereka mau dan inginkan.

Keputusan yang diambil berdasarkan pertimbangan tradisi, nilai nilai dan mempunya alasan dan argumentasi yang lugas.

Setiap keputusan yang diambil oleh individu harus menuju pada pengkuantifikasian keputusan akhir dalam satuan unit moneter.

Dalam model produksi dari kapitalisme, tasionalitas berarti kepuasan yang dapat dicapai dengan prinsif efisiensi dan tujuan ekonomi itu sendiri

Perilaku seorang individu yang rasional dalam mencapai kepuasan berdasrkan kepentingan sendiri yang bersifat material akan menuntun pada perbuatan barang barang sosial yang berguna bagi kemaslahatan umat.

Pilihan dapat dikatan rasional jika pilihannya secara keseluruhan dapat dijelaskan oleh syarat syarat hubungan konsisten pilihan yang lebih disukai dengan definisi penampakan pilihan yang lebih disukai.

Dari penjelasan diatas dapat digambarkan bahwa rasionalitas dalam banyak ekonomi literatur berarti kepentingan sendiri dan pada saat bersamaan konsisten pada pilihan berdasarkan tujuan yang ingin dicapai, dimana bisa dikuantifikasikan menuju maksimalisasi beberapa ide kesejahteraan umum.

\section{Rasionalitas, Antara Imanensi dan Transendensi}

Hal yang harus dirubah mengenai cara pandangan mensikapi rasionlitas adalah munculnya transformasi kearah transendensi yang harusnya didasarkan oleh manusia secara keseuruhan, meskipun kelemahan berpentingan adalah ia masih bersifat normatif tinggal bagaimana formulasi membumi cara pandang tersebut, (FSEI, 2008).

\section{Dari Self Interest ke Social Interest (Regigiun Alturisem)/Social Consideration}

Manusia pribadi harus mengutamakan hidup dengan mentingakan diri sendiri, hidup disini tidak semata-mata hidup dari aku yang partikultural (hidup yang menganggapsendiri dan terpisah denga orang yang lain). Melainkan hidup prinsip ini mengacu pada hidup dari aku yang universal, aku alam, atau singkatnya akunya siapa saja, atau lebih tepatnya pribadi (self) dalama kepentingan pribadi (selfinterest) harus dibaca sebagai entitas transendental - universal dan bukan sekedar pribadi aku atau dia yang partikultural. Kepentingan diri sendiri tersebut merupakan prinsip conatus essendi, yang bertentangan dengan conatus essendi nya Thomas Hobbes yang cenderung mengejar kepentingan sendiri bahkan dengan mengorbankan kepentingan orang lain sekalipun. (FSEI, 2008, Smith, 1982, Keraf, 1996).

\section{Extented Time Horizon}

Dalam islam. (1) waktu tidak dibatasi hanya pada masa kini, tetapi megembang secara horizon (2) waktu sangat penting dan sangat bernilai, nilai waktu tergantung pada bagaimana seseorang memanfatkan waktunya semakin produktif seorang memanfatkannya, semakin banyak nilai yang diperolehnya, bagi setiap orang sehari adalah $24 \mathrm{Jam}$, tetapi nilai waktunya akan berbeda-beda tentunya, tentu hal tersebut dapat diukur salah satunya dengan moneter dimana setiap orang akan selalu berorientasi padanya. (Karim, 2015) 


\section{Islamic World -View On Uncertaint}

Dalam islam, fenomena didunia ini tidak ada yang pasti kecuali kematian, temasuk fenomena bidang apapun dalam Ekonomi, perencanaan yang matang. Kordinasi yang sistematis menajeman yang profesional tidak ada yang menjamin kepastian sebuah aktivitas yang berujung keputusan final. Efek time horizon membuat orang akan tergerak untuk lebih arif bahwa dalam kekeuatan transentral yang bisa dirubah segala bahwa human proses and God dispose menjadi doktrin manusia menghadapi ketidak pastian

Konsep tawakal bisa dipahami bukan pasrah tanpa usaha melainkan menyerahkan berbagai hal yang supernatural berkenanan dengan ketidakmampuan untuk mengatasi problem hidup dan ketidakpastian fenomena yang bersinggung dengan manusia, dalam konsepnya ketidakpastian terjadi kerena dua hal, yaitu, (1) terjadi karena fenomena alam, (2) terjadi rekayasa manusia, Antara feneomena alam dan rekayasa manusia dapat berakibat kepada berbagai aspek kehidupan manusia. Isu aktual bisa dilihat dari climate change, (perubahan iklim) yang secara langsung maupun tidak langung merubah peta kebijakan perekonomian dunia baik lokal,(dalam nergei) maupun internasional dan merambah semua aspek dan level ekonomi. (PSEI; 2008).

\section{Konsep Rasionalitas}

Sebelum membahas rasionalitas lebih jauh, alangkah baiknya jika harus mengetahu terlebih dahulu apa yang dimaksud oleh para pakar ekonom ketika mereka mengatakan bahwa suatu keputusan yang diambil oleh manusia adalah bersifat rasional. Teori tingkah laku dalam ekonomi tergantung pada asumsi asumsi rasionalitas. Disamping itu teori tingkah laku manusia ekonomi yang melandasi pengambilan keputusan dalam ekonomi, dan keadaan keadaan yang secara khusus memotivasi kemunculannya. (Kuper, 2000) Setiap orang mempunya pandangan yang berbeda beda terkait pegertian rasionalitas akan tetapi pada dasarnya memiliki kesamaan secara fundamental. Kesamaan tersebut di istilahkan dalam ekonomi kepuasan. Manusia cenderung ingin memuaskan dirinya. Namun untuk memenuhi hasrat kepuasan tersebut berbeda beda. Dalam pandangan ekonomi konvensional manusia dianggap rasional apabila dapat memenuhi keinginannya yang bersifat materi. Pandangan tersebut berbeda dengan asumsi ekonomi Islam. Islam memandang banhwa manusia dikatakan rasional apabila dapat memenuhi kebutuhan dan keinginannya untuk tujuan jangka panjang nonmateri (akhirat).

Dari uraian diatas dapat dipahami bahwa perilaku manusia, pilihan manusia dan alat pemuas yang terbatas. Unsur perilaku manusia muncul sebagai bagian dari aplikasi naluriah manusia untuk mencari kesejahteraan hidup. Sehingga itu harus diwujudkan melalui aktivitas. Perilaku ini tentunya merupakan cerminan dari apa yang ada dalam diri pelakunya. Yang berupa kepercayaan, kecenderunganberpikir, tata nilai, pola pikir dan juga ideology. Setiap manusia memilih apa yang terbaik untuk hidupnya. Dan apa yang dipilih merupakan hal yang wajar wajar saja, sebab manusia punya rasa, idealism dan ukuran ukuran serta kecenderungan tertentu yang menjadi standar yang membentuk hidupnya. Pilihan ini juga tergantung pada apa yang ada dibalik pelakunya.

Dalam bangunan terminologi diatas, konsep rasionalitas itu muncul. Setiap orang yang dapat mencari kesejahteraan hidupnya (kekayaan material atau non materi) dengan cara melakukan pilihan pilihan yang tepat bagi dirinya.(Karim; 2015) Dengan prinsip bahwa jangan sampai dia tidak mendapatkan pilihan itu karena terbatasnya ketersediaan, maka orang tersebut dianggap melakukan tindakan yang rasional. Dalam lungkup yang lebih khusus seorang produsen dianggap rasional jika ia dapat mencapai tujuan usahanya dengan cara melakukan pilihan strategi. Denikian juga dengan consume, ia dianggap rasional, jika ia dapat memenuhi kepuasannya. Apakah kepuasan tersebut bersifat jangka pendek maupun jangka panjang tergantung dari konsumen itu sendiri.

Konsep rasionalitas yang diukur dari kepentingan pribadi mengundang banyak permasalahan. Beberapa ungkapan keberatan diajukan oleh Syed Agil dalam tulisannnya "Rationality in Economic Theory, A Critical Appraisal", antara lain; pertama, rasionalitas mempunyai watak terlalu menuntut dan 
membatasi. Konsep rasionalitas menuntut pelakuekonomi untuk selalu tahu informasi. Ia dipaksa untuk mengetahui semua hal yang dapat memenuhi kepuasannya, baik cara ataupun hasilnya. Karena kepuasan itu diperoleh dari keserbatahuannya. Keserbatahuan itu merupakan tuntutan mutlak. Sementara di sisi lain, ia dibatasi oleh kepentingannya sendiri untuk memaksimalisasi kepuasannya yang diwujudkandengan cara menekan emosi dan perasaannya yang meluap-luap. Ia dipaksa untuk tetap memokus pada kepentingan pribadi tersebut dengan membatasi diri dari keterlibatan dengan kepentingan-kepentingan orang lain. (Muqorobin,2004). Kedua, rasionalitas membuat pelakunya sebagai bukanmanusia aktual. Manusia menjadi tidak realistis, karena orientasinya hanya mengejar kepuasanyang seringkali di luar jangkauannya. (Muqorobin, 2004) Ketiga, rasionalitas membuat manusia menjadi terlalu materialistik. Ini karena semuanya diukur dengan benda. Implikasinya adalah segala yang tidak nampak seperti; perasaan, empati, jiwa kesederhanaan, kasih sayang, cinta dan lainlain kurang diperhatikan. (Muqorobin, 2004).

\section{Aksioma-Aksioma Pilihan Rasionalitas}

Menurut ilmu ekonomi konvensional, ada prinsip-prinsip yang biasa digunakan dalam rasionalitas ekonomi(Rianto \& Amalia; 2010),

\section{Kelengkapan (Completeness)}

Prinsip ini mengatakan bahwa setiap individu selalu dapat menentukan keadaan mana yang lebih disukainya diantara dua keadaan. Bila A dan B merupakan dua keadaan yang berbeda, maka individu selalu dapat menemukan secara tepat satu diantara kemungkinan berikut,

A lebih disukai daripada B

B lebih disukai daripada A

A dan B sama-sama disukai

A dan B sama-sama tidak disukai

\section{Transitivitas (Transitivity)}

Prinsip ini menerangkan mengenai konsistensi seseorang dalam menentukan dan memutuskan pilihannya bila dihadapkan oleh beberapa alternatif pilihan produk. Dimana jika seseorang individu mengatakan bahwa "produk A lebih disukai daripada produk B", dan "produk B lebih disukai daripada produk $C^{\prime \prime}$, maka ia pasti akan mengatakan bahwa "produk A lebih disukai produk C". prinsip ini sebenarnya untuk memastikan adanya konsistensi internal di dalam diri individu dalam hal pengambilan keputusan.

Hal ini menunjukkan bahwa setiap alternatif pilihan seorang individu akan selalu konsisten dalam memutuskan preferensinya atas suatu pruduk dibandingkan dengan produk lain.

\section{Kesinambungan (Continuity)}

Prinsip ini menjelaskan bahwa jika seorang individu mengatakan "produk A lebih disukai daripada produk B", maka setiap keadaan yang mendekati produk A pasti juga akan lebih disukai lebih dari pada produk B. Sebagai contoh dimana seorang individu lebih menyukai mobil dengan merek Honda daripada merek Suzuki, maka setiap tipe model dari mobil merek Honda apapun akan jauh lebih disukai dari pda tipe model apapun dari model merek Suzuki.

\section{Lebih banyak selalu lebih baik (The more is always the better)}

Prinsip ini menjelaskan bahwa jumlah kepuasan akan meningkat, jika individu mengonsumsi lebih banyak barang atau produk tersebut. Hal ini bisa di jelaskan dengan kurva kepuasan konsumen -- dalam ilmu ekonomi hal ini dikenal dengan kurva indiferen (indeference curve) -- yang semakin meningkat akan memberikan kepuasan yang lebih baik. Sehingga konsumen cenderung akan selalu menambah konsumsinya demi kepuasan yang akan didapat. Meskipun dalam peningkatan kurva ideferent ini akan dibatasi oleh keterbatasan anggaran (budget constraint)

Menurut Adiwarman Karim, (Karim ;2015) ada dua tipe rasionalitas baik individu maupun kolektif.,

Rasionalitas yang didasarkan atas kepentingan pribadi (self-interest rationality). Menurut Edgeworth bahwa prinsip pertama dalam Ilmu ekonomi setiap pelaku ekonomi 
digerakkan oleh kepentingan pribadi seorang individu. Kepentingan pribadi dalam konteks ini bukan sekedar mengejar tujuan -tujuan yang bersifat kekayaan materi atau bendawi. Tujuan-tujuan tersebut bisa berbentuk prestise, cinta, aktualisasi diri dan lain-lain. Serta dapat pula berupa sebuah pencapain individu menjadi lebih baik dan membuat lingkungan sekelilingnya menjadi lebih baik juga pada saat yang bersamaan.

Rasionalitas berdasarkan tujuan yang ingin dicapai (present aim rationality). Asumsi dari teori ekonomi ini bahwa manusia tidak selalu bersikap mementingan dirinya sendiri. Teori ini berasumsi bahwa manusia menyesuaikan preferensinya dengan sejumlah aksioma

\section{Rasionalitas dalam Ekonomi Kapitalis, Sosialis dan Islam}

\section{Kapitalis}

Sistem ini menegaskan semua sumber merupakan milik pribadi. Perusahaan dijalankan pengusaha dengan tujuan untuk mendapatkan laba yang sebanyak-banyaknya. Rumah tangga berusaha untuk berusaha memperoleh pendapatan sebanyakbanyaknya. Tak ada perusahaan dan rumah tangga yang cukup besar di pasar untuk mempengaruhi harga barang yang dijual dan dibeli, dengan kata lain terdapat persaingan sempurna. Pada pihak pemerintah milik dilindungi perjanjian dilindungi, perjanjian dilindungi, dan suatu pajak yang rendah dipungut. Perusahaan mempunyai kebebasan usaha dan rumah tangga punya kemerdekaan untuk memilih. Harga bergerak dengan bebas. Mekanisme pasar mengkordinir produksi dan membagikan pendapatan. Buruh tidak terorganisir dan faktor produksi lain menerima balas jasa yang diberikan oleh pasar kepada mereka (Grossman, 1995)

Ada beberapa indikator yang menjadi kelemahan sistem ekonomi kapitalis yaitu, (Grossman, 1995)

Tidak merata

Tidak selaras

Maximalisasi Profit

Krisi Moral

Materialitis

Mengesampingkan Kesejahteraan
Umar Chapra menjelaskan bahwa kapitalis akan menjurus kepada; kebebasan individu yang tidak terbatasi untuk memenuhi kepentingan pribadi, kepemilikan, dan pengelolaan privat; ekspansi kekayaan yang dipercepat dan produksi maksimum serta pemenuhan kebutuhan menurut preferensi individual; dan lebih mengutamakan kekuatankekuatan pasar dalam lokasi dan distribusi sumber-sumber daya dan meminimalkan peran pemerintah atau penilaian kolektif (Chapra, 2000)

Syaid Muhammad Baqir al-Shadr dalam bukunya Keunggulan Ekonomi Islam yang diterjemahkan oleh M. Hasem menjelaskan akibat buruk ekonomi kapitalis, yaitu berkuasanya kaum mayoritas atas kaum minoritas yang kepentingankepentingannya dikuasi oleh kaum mayoritas, akibatnya tidak ada kendali atas ekploitasi perekonomian dengan memperoleh investasi yang tidak terbatas dalam proyek yang sah ataupun tidak sah (al-Sadar, 2000)

\section{Sosialis}

Menurut M. Umar Chapra Ada beberapa indikator yang menjadi kelemahan sistem ekonomi Sosialis yaitu (Chapra; 2000)

\section{Pemilikan harta oleh negara}

Seluruh bentuk produksi dan sumber pendapatan menjadi milik negara dan diatur kemudian lewat negara, dipergunakan untuk seluruh rakyat. Rakyat tidak mempunyai hak untuk memiliki harta kecuali harta-harta tertentu yang telah ditetapkan oleh negara.

Motivasi masyarakat untuk bekerja tidak didasarkan atas nilai kepemilikan yang ia akan dapatkan kelak setelah bekerja tetapi lebih dikarenakan adanya aturan yang ketat atas apa yang harus mereka kerjakan. Tetapi, bukan berarti rakyat tidak mendapatkan hasil dari pekerjaannya. Rakyat mendapatkan hasilnya melalui pembagian yang rata yang dilakukan negara.

Perhatian negara pada bidang-bidang tertentu, menimbulkan kecenderungan lebih banyak mengalokasikan hasil produksi pada sektor yang diprioritaskan, misalnya ketika masa perang negara sosialisasi lebih cenderung 
memperhatikan bagaimana sektor ekonomi dialihkan untuk mengakomodir kebutuhan perang dibanding masalah kesejahteraan rakyat. Akibatnya, kapasitas kerja rakyat dikondisikan pada target produksi negara yang sedang perang. Dorongan masyarakat untuk bekerja sebagai hak individu untuk memiliki harta atau memanfaatkan produksi tidak diperbolehkan. Dengan demikian individu secara langsung tidak mempunyai hak atas kepemilikannya

\section{Kesamaan Ekonomi}

Sistem ekonomi sosialis menyatakan walaupun sulit ditemui di semua negara komunis bahwa hak-hak individu dalam suatu bidang ekonomi ditentukan oleh prinsip kesamaan. Prinsip ini didasarkan atas kebutuhan minimal perorang dalam hidup perharinya. Kesamaan dalam memenuhi kebutuhan ekonominya didasarkan atas asumsi bahwa setiap orang mempunyai hak yang sama untuk mendapatkan pelayanan. Sehingga potensi yang berkembang dikarenakan latar belakang kemampuan alami kurang mendapat perhatian oleh negara. Keadaan ini menjerumuskan pada kehidupan masyarakat yang beku dan tidak ada dinamika, karena apresiasi hidup manusia terbelenggu oleh berbagai aturan negara yang lebih dipengaruhi oleh perspektif baku tentang masalah kemasyarakatan. Bentuk negara dalam mendinamisasikan masyarakatpun ada, tetapi dengan cara mengkonsentrasikan rakyat pada bidangnya secara penuh, misalnya dalam bidang pendidikan dan olahraga.

\section{Disiplin Politik}

Untuk mencapai tujuan di atas, keseluruhan negara diletakkan di bawah peraturan kaun buruh, yang mengambil alih semua aturan produksi dan distribusi. Kebebasan ekonomi serta hak pemilikan harta dihapus. Aturan yang dipergunakan sangat ketat untuk lebih mengefektifkan praktek sosialisme. Hal ini juga mengatur kehidupan rakyat. Maka keberlangsungan sistem sosialis ini tidak akan berlaku ideal sebagaimana dicita-citakan oleh Marx, Lenin dan Stalin. Praktek sosialisme seperti ini yang menunjukkan bahwa sebenarnya sosialisme tidak memenuhi karakter sistem yang mampu meningkatkan peran rakyat dalam berpartisipasi terhadap negara. Nasionalisme kalau dibentuk dalam disiplin politik yang ketat tidak akan menimbulkan nasionalisasi, malah cenderung akan timbul sikap antipati terhadap sistem yang ada. Misalnya, tragedi di lapangan merah Tianamen Cina merupakan aktualiasasi kebebasan untuk berbicara sebagai rakyat Cina terhadap pemerintah yang menggunakan aturan yang ketat terhadap rakyat.

\section{Islam}

Rasionalitas ekonomi syariah dapat dilihat pada asas-asas Ekonomi Syariah dan prinsip dasar sistem yang dipakai. pengaruh kepentingan pribadi dan dukungan kaum agamawan menjadi jastifikasi untuk memperkaya diri sendiri dan mengabaikan kepentingan sosial, kenyataan yang kaya terusmemperkaya diri dan yang miskin semakin diekspolitasi dan dibui mimpi terus merambah semua lini perekonomian alihalih berbicara kesejahteraan masyarakat, yang menjadi target ekonominya adalah monopoli gaya baru.

Jika dalam ekonomi konvensional menusia disebut rasional secara ekonomi jika mereka selalu memaksimumkan utility untuk konsumen dengan keuntungan untuk produsen, maka dalam ekonomi islam seorang pelaku ekonomi, produsen, konsumen fakan berusaha untuk memaksimalkan maslahah (BI \& P3EI-UII; 2007),

Islam adalah agama yang sarat dengan etika, Naqvi mengungkapkan bahwa etika dalam Islam dapat dikelompokkan menjadi 6 aksioma pokok, yaitu, tauhid, keadilan, kebebasan berkehendak dan pertanggungjawaban, halal, dan sederhana(Naqvi; 1985)

Komitmen Islam pada persaudaraan dan keadilan menuntut semua sumber daya yang tersedia bagi ummat manusia. Amanat suci tersebut harus diarahkan untuk mewujudkan maqashid syariah, yakni, (1) Pemenuhan kebutuhan, (2) Penghasilan yang diperoleh dari sumber yang baik; (3) Distribusi pendapatan dan kekayaan yang adil, dan (4) pertumbuhan dan stabilitas. (Chapra ,1999) 
Beberapa pakar ekonomi islam membuat batasan terhadap rasionalitas dalam ekonomi islam Konsep asas rasionalisme Islam menurut Monzer Kahf (Tim Penulis UII,2008),

\section{Konsep kesuksesan}

Islam membenarkan individu untuk mencapai kesuksesan di dalam hidupnya melalui tindakantindakan ekonomi, namun kesuksesan dalam Islam bukan hanya kesuksesan materi akan tetapi juga kesuksesan di hari akhirat dengan mendapatkan keridhaan dari Allah SWT. Kesuksesan dalam kehidupan muslim diukur dengan moral agama Islam, bukan dengan jumlah kekayaan yang dimiliki. Semakin tinggi moralitas seseorang, semakin tinggi pula kesuksesan yang dicapai. Kebajikan, kebenaran dan ketakwaan kepada Allah SWT merupakan kunci dalam moralitas Islam. Kebajikan dan kebenaran dapat dicapai dengan perilaku yang baik dan bermanfaat bagi kehidupan serta menjauhkan diri dari kejahatan. Ketakwaan kepada Allah dicapai dengan menyandarkan seluruh kehidupan hanya karena (niyat), dan hanya untuk (tujuan) Allah, dan dengan cara yang telah ditentukan oleh Allah

\section{Jangka waktu perilaku konsumen}

Islam membenarkan individu untuk mencapai kesuksesan di dalam hidupnya melalui tindakantindakan ekonomi, namun kesuksesan dalam Islam bukan hanya kesuksesan materi akan tetapi juga kesuksesan di hari akhirat dengan mendapatkan keridhaan dari Allah SWT. Kesuksesan dalam kehidupan muslim diukur dengan moral agama Islam, bukan dengan jumlah kekayaan yang dimiliki. Semakin tinggi moralitas seseorang, semakin tinggi pula kesuksesan yang dicapai. Kebajikan, kebenaran dan ketakwaan kepada Allah SWT merupakan kunci dalam moralitas Islam. Kebajikan dan kebenaran dapat dicapai dengan perilaku yang baik dan bermanfaat bagi kehidupan serta menjauhkan diri dari kejahatan. Ketakwaan kepada Allah dicapai dengan menyandarkan seluruh kehidupan hanya karena (niyat), dan hanya untuk (tujuan) Allah, dan dengan cara yang telah ditentukan oleh Allah

\section{Konsep kekayaan}

Kekayaan dalam konsep Islam adalah amanah dari Allah SWT dan sebagai alat bagi individu untuk mencapai kesuksesan di hari akhirat nanti, sedangkan menurut pandangan konvensional kekayaan adalah hak individu dan merupakan pengukur tahap pencapaian mereka di dunia.

\section{Konsep barang}

Konsep barang dalam pandangan Islam selalu berkaitan dengan nilai-nilai moral. Dalam alQuran dinyatakan dua bentuk barang yaitu, al-tayyibat (barangan yang baik, bersih, dan suci serta berfaedah) dan barangan al-rizq (pemberian Allah, hadiah, atau anugerah dari langit) yang bisa mengandung halal dan haram. Menurut ekonomi Islam, barang bisa dibagi pada tiga kategori yaitu, barang keperluan primer (daruriyyat) dan barang sekunder (hajiyyah) dan barang tersier (tahsiniyyat). Barang haram tidak diakui sebagai barang dalam konsep Islam. Dalam menggunakan barang senantiasa memperhatikan maqasid syariah (tujuan syariah). Oleh karena itu konsep barang yang tiga macam tersebut tidak berada dalam satu level akan tetapi sifatnya bertingkat dari daruriyyat, hajiyyat dan tahsiniyyat

\section{Etika konsumen}

Islam tidak melarang individu dalam menggunakan barang untuk mencapai kepuasan selama individu tersebut tidak mengkonsumsi barang yang haram dan berbahaya atau merusak. Islam melarang mengkonsumsibarang untuk israf (pembaziran) dan tabzir (spending in the wrong way) seperti suap, berjudi dan lainnya

Siddiqi terkonsentrasi pada bidang ekonomi konsumsi terkonsentrasi pada bidang konsumsi menyatakan bahwa hal pertama yang harus disadari konsumen adalah bahwa dirinya sekarang sebagai muslim tentunya standar hidup yang digunakan adalah standar Islam, salah satunya bahwa untuk mencapai kepuasan, konsumen tidak lagi hanya mengejar maksimasi kepuasan semata secara ekonomi, inilah yang disebut Islamic Rasionality. (FSEI; 2008, Sidiqqi; 1972) 
Dalam konteks rasionalitas dalam konsumsi yang lebih spesifik Fahim, Khan, membadakan antara maslahah dan kepuasan, maslahah dikoneksikan dengan keingin wants, ia menderivasikan pandangan kepada konsep maqasid syariah, dan maslahah yang berujung pada li-mashalih al-ibadah (untuk kemaslahatan hamba manusia) (FSEI; 2008)

Berkaitan dengan rasionalitas perilaku muslim dalam kepuasan (utility) Anas Zarqa, membedakan secara fundamental antara homo economic dan homo islamicus dimana fungsifungsi yang melekat pada homo economicus melekat juga pada homo islamicus, yang membedakanya adalah pahala, reward dan hukuman dosa di akhirat (FSEI; 2008)

Kepuasan optimal dapat diketahui dari perintah (hadits) nabi, yaitu untuk berhenti makan sebelum kenyang. Hal ini disebabkan karena pada saat itulah kondisi kreasi dapat diperoleh. Gambaran kepuasan dan keadaan siap kreasi optimal diperoleh, dapat digambarkan sebagai berikut. (Muhamad,2004)

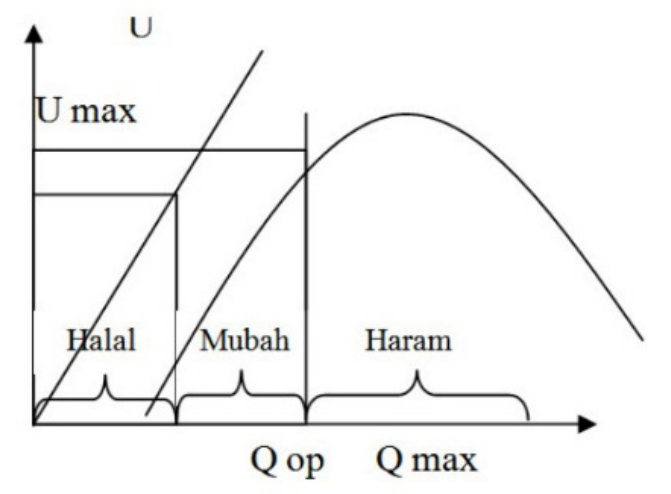

Pada gambar di atas dapat dilihat bahwa kepuasan optimal yang menghasilkan keadaan siap kreasi maksimal berada pada titik di mana pertambahan kepuasan yang diperoleh atas pertambahan jumlah barang yang dikonsumsi sama dengan harga barang. Dalam Islam ada tiga hukum yang berlaku dalam konsumsi, yaitu halal, mubah, dan haram; halal berlaku pada daerah I (orang wajib makan); mubah berlaku pada daerah II yaitu daerah di mana seseorang harus berhati-hati dalam makan karena telah mencapai kepuasan optimal; dan makan menjadi haram jika telah menempati daerah III yaitu bila seseorang telah mencapai kepuasan maksimum tetapi masih terus menambah barang yang dimakannya, pada saat makan berada di dU/ $\mathrm{dQ}=0$ berarti pada saat inilah seseorang telah mencapai kepausan optimum. Sedangkan bila telah mencapai kepuasan maksimum, maka harus berhenti makan karena bila melebihi batas-batas kemampuan konsumsi barang yang semula halal bisa menjadi haram.

Dengan demikian economic rationality from Islamic view bermakna, (1) konsisten dalam pilihan ekonomi (2) Content pilihan tidak mengandungi haram, israf, tabdzir, mudarat kepada masyarakat (jadi senantiasa taat kepada rules Allah) (3) Memperhatikan faktor eksternal seperti kebaikan hati (altruism) yang sesungguhnya, interaksi sosial yang mesra. Menurut Siddiqi, perilaku rasional dalam ekonomi Islam tidak selalu mengindikasikan pemaksimuman.(Rational behaviour in Islamic economics doesn't necessarily imply maximization) (Tim Penulis MSI UII; 2008)

\section{KESIMPULAN}

Rasionalitas dalam ekonomi bahwa manusia berprilaku secara rasional (masuk akal), dan tidak akan secara sengaja membuat keputusan yang menjadikan mereka menjadi lebih buruk. Rasionalitas memiliki dua tipe yaitu, Self interest rationality dan Present-aim rationality.

Terdapat perbedaan mendasar antara rasionalitas ekonomi konvensional dan ekonomi Islam. Perbedaan mendasar adalah sember pengembalian dasar sebagai filosfinya dan rentang waktu yang melingkupinya, Islam lebih menekankan pada konsep need daripada want dalam menuju maslahah, need lebih bisa diukur daripada want. Menurut Islam, manusia mesti mengendalikan dan mengarahkan want dan need sehingga dapat membawa maslahah dan bukan madarat untuk kehidupan dunia dan akhirat.

Konsep tujuan konsumen rasional seorang muslim, bahwa seorang muslim dalam melakukan konsumsi pengeluaran harus mempertimbangkan perbuatan israf dan tabzir. Di dalam konsumsi harus memperhatikan barang yang dikonsumsi pada periode waktu tertentu dan barang tahan lama yang dikuasai dan pengeluaran zakat, infaq, serta shadaqah sebagai bekal di kehidupan akhirat. 


\section{DAFTAR PUSTAKA}

Adam Kuper, (2000), Ensiklopedia ilmu ilmu sosial, diterterjmahkan oleh Haris Munandar, Jakarta, GrafindoPersada

Adiwarman A. Karim (2015), Ekonomi mikro Islam, Jakarta, GrafindoPersada,

al-Shadr, Syahid Muhammad Baqir, (2002), Keunggulan Ekonomi Islam, judul asli, Islam and Schools of Economic, Jakarta, Pustaka Jahra,

Arif, M. Nur Rianto Al dan Euis Amalia, (2010), Teori Mikroekonomi, Suatu Perbandingan Ekonomi Islam dan Ekonomi Konvensional, Jakarta, Kencana

Chapra, M. Umar, (2000), Islam dan Pembangunan Ekonomi Jakarta, Gema Insani. (1999) Islam dan

Tantangan Ekonomi, Islamisasi Ekonomi Kontemporer, Surabaya, Risalah Gusti

Direktorat Perbankan Syariah Dan Pusat Pengkajian Dan Pengembangan Ekonmi Islam, (2007), Text Book Ekonomi Islam, Jakarta , BI \& P3EI-UII

Grossman, Gregory, (1995). Sistem-sistem Ekonomi, diterjemahkan Anas Siddik ,Jakarta, Bumi Aksara,

Moleong, Lexy J., (2000), Metodologi Penelitian Kualitatif, Bandung: Remaja Rosdakarya,

Monzer Kahf, (1992), "The Theory of Consumption" dalam Sayyid Tahir et al. (ed.), Readings in Microeconomics An Islamic Perspective. Petaling Jaya, Longman Malaysia Sdn Bhd,

Muhammad, (2004). Ekonomi Makro Dalam Perspektif Islam, Yogyakarta, BPFE,

Muqorobin, Masyhudi, Landscape for The Future Islamic Economics, Jurnal ISEFID, vol. 3, No. 3, Desember 2004

Naqvi, Syed Nawab Haidar (1985), Etika dan Ilmu Ekonomi, Suatu Sintesis Islami, Bandung, Mizan

Nasution dkk, (2007) Pengenalan Ekslusif Ekonomi Islam, Kencana Prenada Group, Jakarta,

Sidiqi, Muhammad Nejatullah, (1972)Economic Enterprise in Islam, Pakistan, Islamic Publication,

Smith; Adam, (1982), Theori of Moral Sentiments, Indianapolis, liberty Clasic II,ii 2.1

Sony. Keraf A. (1996) Pasar Bebas, Keadilan Dan Peranan Pemerintah, "Telaah Atas Etika Politik Ekonomi Adam Smith, (Yogyakarta, Kanisius,

Tim Penulis FSEI, (2008) Filsafat Ekonomi Islam, (Yogyakarta , FSEI UIN Sunan Kalijaga,

Tim Penulis MSI UII, (2008). Menjawab Keraguan Berekonomi Syariah.Yogyakarta, Safiria Insania Press Bekerjasama dengan MSI UII 